There is a divide between the energy and joy with which the public engages in Shakespeare and what we do as academics. The Recreational Shakespeare series crosses this divide with a series of new, playful, and challenging voices that look at public engagements with Shakespeare in popular culture and education.

Recreational Shakespeare has two emphases. The first is the study of the ways that artists have recreated Shakespeare and his texts on screen, stage, radio, the internet, in other performance media, and in novels, comics, and poetry. Adaptations, riffs, and reimaginings that are clearly inspired by Shakespeare and those that partly or completely hide their origins are in the purview of this series. The other "recreational" element emphasizes the ways these artifacts are consumed as people spend their money and free time enjoying them. Books in this series are quite short. Academic rigor is required. Academic language is not. Recreational Shakespeare books are fun.

The General Editors invite new and established authors to contribute to the Recreational Shakespeare series. We are looking for writers of monographs and editors of anthologies. Please visit the website for a more technical introduction and all the contact information: https://arc-humanities.org/our-series/arc/ recs/\#1476219418444-63593f1f-da0f.

Jeffrey Kahan

University of La Verne

Eric S. Mallin

University of Texas, Austin

Michael P. Jensen

Contributing Editor, Shakespeare Newsletter 


\section{SHAKESPEARE AND SUPERHEROES}

BY JEFFREY KAHAN

ARChumanities press 


\section{British Library Cataloguing in Publication Data}

A catalogue record for this book is available from the British Library

\section{(C) 2018, Arc Humanities Press, Leeds}

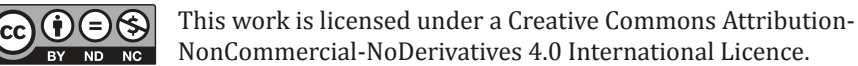

The author asserts their moral right to be identified as the author of their part of this work.

Permission to use brief excerpts from this work in scholarly and educational works is hereby granted provided that the source is acknowledged. Any use of material in this work that is an exception or limitation covered by Article 5 of the European Union's Copyright Directive (2001/29/EC) or would be determined to be "fair use" under Section 107 of the U.S. Copyright Act September 2010 Page 2 or that satisfies the conditions specified in Section 108 of the U.S. Copyright Act (17 USC §108, as revised by P.L. 94-553) does not require the Publisher's permission.

ISBN: 9781942401773

e-ISBN: 9781942401780

https://arc-humanities.org

Printed and bound by CPI Group (UK) Ltd, Croydon, CR0 4YY 
